\title{
Impact of Pink Pigmented Facultative Methylotroph and PGRs on Water Status, Photosynthesis, Proline and NR Activity in Tomato under Drought
}

\author{
R. Sivakumar*, G.K. Nandhitha, P. Chandrasekaran, \\ P. Boominathan and M. Senthilkumar
}

\author{
Department of Crop Physiology, Tamil Nadu Agricultural University, \\ Coimbatore - 641003 , India \\ *Corresponding author
}

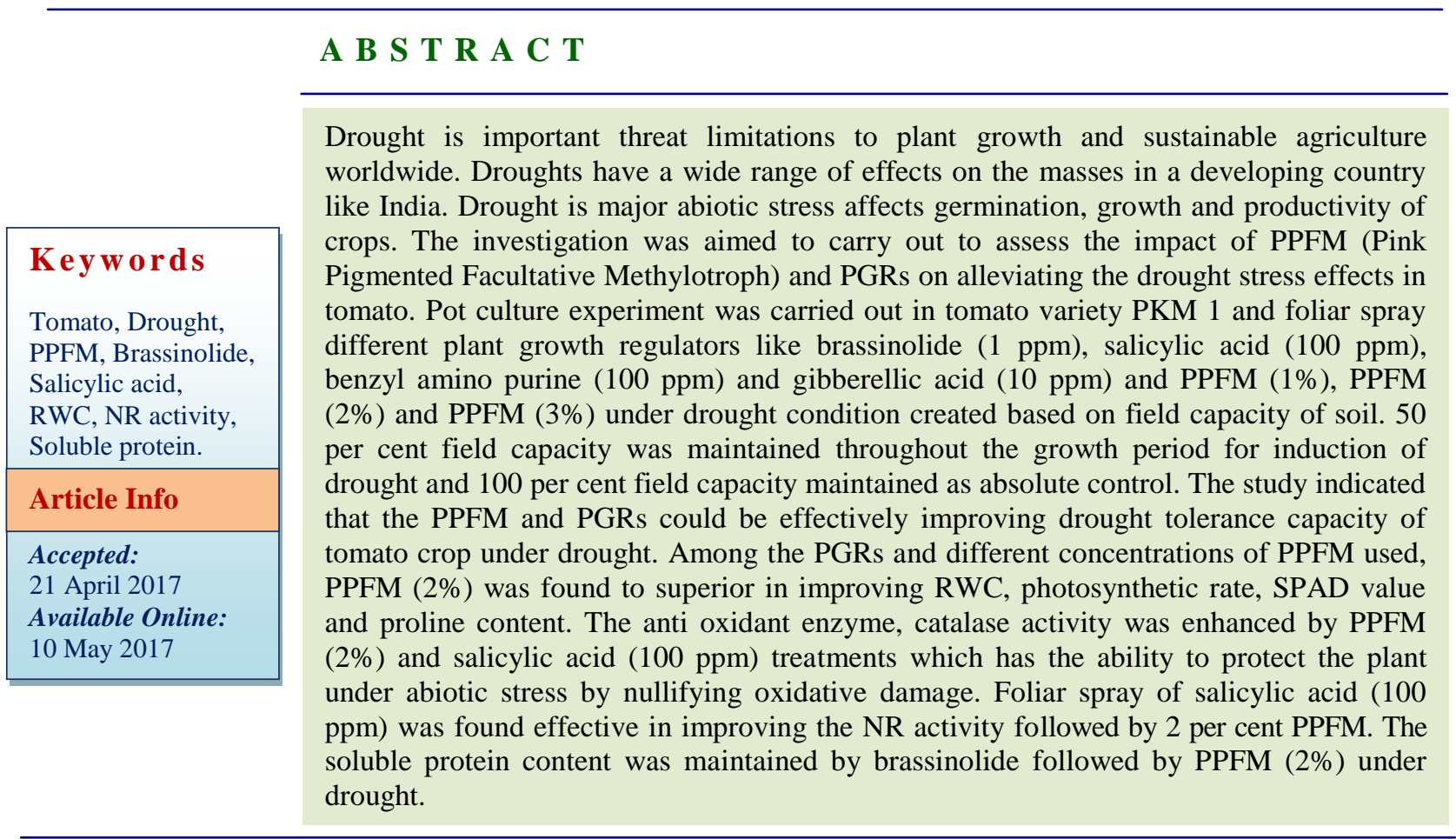

\section{Introduction}

Abiotic stress has been estimated that more than half of the yield potential of major crops is mainly affected due to unfavorable growing environments such as drought (Cortina and Culianez-Macia, 2005). The problem of drought is increasing day by day with reduction in production of crops (Qayyum and Malik, 1988). This can be recovered to a certain extent with the applications of plant growth regulators (PGRs) that play an important role in several physiological and molecular processes of plants. In addition, PGRs used as potential tools to increase defense mechanisms against any stress conditions (Nair et al., 2009). Hence, different approaches were adopted to alleviate the effect of drought and one among those is the exogenous application of plant growth 
regulators (Ashraf and Foolad, 2007) and PGPR (Plant Growth Promoting Rhizobacteria). Methylobacterium species are a group of bacteria known as pink-pigmented facultative methylotrophs, or PPFMs (Green and Bousfield, 1983) and exogenous application of PPFM produces some benefit in alleviating the adverse effects of drought stress and also improves germination, growth, development, quality and yield of crop plants (Hayat et al., 2010). Van Loon et al., (1998) reported that environmentally sustainable agricultural systems, the bacterial inoculants that provide cross protection against both biotic and abiotic stress would be highly preferable.

The benefit effect of gibberellins in maize (Tuna et al., 2008), cytokinins in vigna radiata (Chakrabarti and Mukherji, 2002), salicylic acid in tomato (Hayat et al., 2008) and brassinosteroid in tomato (Vardhini and Rao, 2001) were documented.

Exogenously applied brassinolide alleviated the detrimental effects of drought in maize and remarkably improved the chlorophyll contents, protein, relative leaf water contents (RLWC), proline, and enzymatic antioxidants (Anjum et al., 2011). Saruhan et al., (2012) reported that the exogenous salicylic acid reduced the adverse effects of drought stress in maize and might have a key role in providing tolerance to stress by decreasing water loss and inducing the antioxidant system in plants with leaf rolling, an alternative drought protection mechanism. Application of cytokinin improves the physiological traits in terms of membrane stability index, RWC, and photosynthetic rate at the vegetative stage of wheat (Dwivedi et al., 2014). Based on this background knowledge available, the present investigation was carried out to assess the physiological basis of drought tolerance mediated by PPFM and other PGRs in tomato.

\section{Materials and Methods}

The experiment was carried out in the pot culture under glass house condition. Red sandy soil was used for pot culture experiment. Soil mixture was prepared by using red soil, vermicompost and sand in the ratio of $3: 2: 1$. Pots were filled with $10 \mathrm{~kg}$ of soil. Drought was imposed at first day after transplanting onwards by maintaining soil moisture at 50 per cent field capacity for drought stress by weighing and watering each pot at regular interval. Crop was supplied with fertilizers (NPK) and other cultivation operations including plant protection measures as per recommended package of practices of Tamil Nadu Agricultural University, Coimbatore. The experiment was laid out in completely randomized block design with three replications. The treatments like absolute control (100\% FC), Control (50\% FC), PPFM (1\%), PPFM (2\%), PPFM (3\%), brassinolide (1 ppm), salicylic acid (100 ppm), benzyl amino purine (100 ppm) and $\mathrm{GA}_{3}(10 \mathrm{ppm})$ were used for this experiment. PPFM and PGRs treatments were given as foliar spray at 25 and 45 days after transplanting.

The relative water content (RWC) was estimated according to Barrs and Weatherly (1962) and calculated by using following formula and expressed as per cent.

RWC $=[($ Fresh weight - Dry weight $) /$ (Turgid weight - Dry weight)] x 100

Photosynthetic rate was measured by using Portable Photosynthesis System (PPS) (Model LI-6400 of LICOR inc., Lincoln, Nebraska, USA) equipped with a halogen lamp (640002B LED) positioned on the cuvette. Totally, three measurements were taken in the same leaf. Leaves were inserted in a $3 \mathrm{~cm}^{2}$ leaf chamber and PPFD at $1200 \mu \mathrm{mol}$ photons $\mathrm{m}^{-2}$ $\mathrm{s}^{-1}$ and relative humidity $(50-55 \%)$ were set. 
The readings were taken between 9 am and $11.30 \mathrm{am}$.

SPAD readings were recorded using Chlorophyll Meter (SPAD 502) designed by the Soil Plant Analytical Development (SPAD) section, Minolta, Japan. Soluble protein content of the leaf was estimated at by using folin ciocalteau reagent by following the procedure described by Lowry et al., (1950). $250 \mathrm{mg}$ of leaf sample was macerated with $10 \mathrm{ml}$ of phosphate buffer and the content was centrifuged at $3000 \mathrm{rpm}$ for about 10 minutes. One $\mathrm{ml}$ of the supernatant and 5 $\mathrm{ml}$ of alkaline copper tartarate reagent were mixed with $0.5 \mathrm{ml}$ of folin ciocalteau reagent and the OD value was measured at $660 \mathrm{~nm}$ in the spectrophotometer. The soluble protein content was expressed as $\mu \mathrm{g} \mathrm{g}^{-1}$ fresh weight by using bovine serum albumin as the standard.

The estimation of proline content was adopted by using the protocol of Bates et al., (1973) and amount of proline in the sample is expressed in $\mathrm{mg} \mathrm{g}^{-1}$. $0.5 \mathrm{~g}$ leaf sample was homogenized with $10 \mathrm{~mL}$ of 3 per cent sulphosalicylic acid and centrifuged at 3000 $\mathrm{rpm}$ for 10 minutes. Two $\mathrm{mL}$ of the supernatant was taken and $2 \mathrm{~mL}$ of glacial acetic acid, $2 \mathrm{~mL}$ of ortho phosphoric acid and $2 \mathrm{~mL}$ of acid ninhydrin mixture were added. The contents were allowed to react at $100^{\circ} \mathrm{C}$ for 1 hour under water bath and then it is incubated on ice for 10 minutes to terminate the reaction. The reaction mixture was mixed vigorously with $4 \mathrm{ml}$ toluene for 15 to 20 seconds. The chromophore containing toluene was aspired from the aqueous phase, warmed to room temperature and optical density was read at $520 \mathrm{~nm}$.

Nitrate reductase activity was estimated in fully expanded functional leaves following the method of Nicholas et al., (1976) by using assay medium (Phosphate buffer $+\mathrm{KNO}_{3}+$
Iso propanol), sulphanilamide and NEDH. The enzyme activity was expressed as $\mu \mathrm{mol}$ $\mathrm{NO}_{2} \mathrm{~g}^{-1} \mathrm{~h}^{-1}$ using $\mathrm{KNO}_{2}$ as a standard. Catalase activity was determined by following titration method using potassium permanganate (Gopalachari, 1963) and expressed as $\mu \mathrm{g} \mathrm{H}_{2} \mathrm{O}_{2} \mathrm{~g}^{-1} \mathrm{~min}^{-1}$. The data on various parameters were analyzed statistically as per the procedure suggested by Gomez and Gomez (1984).

\section{Results and Discussion}

\section{Impact of PPFM and PGRs on RWC and photosynthetic rate}

\section{Relative water content (RWC)}

It is the important trait that reflects the tissue water status under stress which has direct relevance to photosynthetic rate through stomatal opening by turgid. RWC is considered as one of the key tool to assess drought tolerance. Haloi and Baldev (1986) revealed that the productivity of the crop may be related to physiological attributes like photosynthetic rate and relative water content. In the present study, RWC decreased up to 32.69 per cent in plants under drought compared to absolute control. Among the PGRs and PPFM used, PPFM (2\%) treatment gave statistically superior relative water content of 64.42 per cent followed by brassinolide $(62.66 \%)$ and salicylic acid (61.24\%) and at 60 DAT (Table 1).

Higher RWC indicates better water status of plant, which in turn cause rapid early growth and maintenance of RWC at reasonably higher level during reproductive phase greatly influences the tolerance under water stress conditions. Zhang et al., (2004) reported that the plant growth regulators like benzyladenine and brassinolide significantly increased leaf water potential and improved chlorophyll content in soybean under water deficit 
condition. From the current study, it is observed that foliar application of PPFM (2\%) increased the relative water content up to 32.12 per cent followed by brassinolide $(28.51 \%)$. The higher relative water content might be due to the osmotic adjustment as reported by Katerji et al., (1997). The positive effect of PPFM might be due to the increment of osmolytes like proline and enhance the water uptake and maintained the water status of the plant. The ameliorative effect of SA might be linked to increased photosynthetic apparatus which in turn considerably increased the biosynthesis of osmotic solutes under droughts stress. These osmolytes might increase the osmotic pressure of cytoplasm and enhance water flow into the different plant organs and tissues. The results of present study corroborate the findings of Maggio et al., (2010) and Li et al., (2009) in tomato.

\section{Photosynthetic rate}

It is the primary determinant of plant growth and yield. Current study showed that drought stress caused significant reduction in photosynthetic rate than normal conditions. The reduction in photosynthesis in drought stress condition was observed as 36.16 per cent when compared to absolute control. The data on the photosynthetic rate revealed significant difference among the treatments and absolute control. Absolute control recorded the highest photosynthetic rate (43.70 $\mu \mathrm{mol} \mathrm{CO}_{2} \mathrm{~m}^{-2} \mathrm{~s}^{-1}$ ) and lowest was recorded in control $\left(23.77 \mu \mathrm{mol} \mathrm{CO} \mathrm{Cm}^{-2} \mathrm{~s}^{-1}\right)$. The maximum photosynthetic rate was observed in brassinolide $\left(36.43 \mu \mathrm{mol} \mathrm{CO} \mathrm{CO}^{-2}\right.$ $\left.\mathrm{s}^{-1}\right)$ followed by PPFM (2\%) treatment $(35.80$ $\mu \mathrm{mol} \mathrm{CO} \mathrm{Cm}^{-2} \mathrm{~s}^{-1}$ ) (Table 1).

Improving the photosynthesis through exogenous application of PGRs and PPFM was extremely useful as it directly correlates with biomass in turn to yield. In current study of PGRs and PPFM tried, brassinolide improved the photosynthetic rate up to 30.57 per cent under drought stress conditions over control. Foliar application of brassinosteroids might increase the light saturated net $\mathrm{CO}_{2}$ assimilation rate ( $\mathrm{Yu}$ et al., 2004). Increased $\mathrm{CO}_{2}$ assimilation rate in leaves was accompanied by the increase in the maximum carboxylation rate of rubisco and a higher quantum yield of PSII electron transport. The findings of present study is in accordance with the findings of Braun and Wild (1984) in wheat and mustard. Methylotrophs inoculation was found to increase the photosynthetic activity by enhancing the number of stomata, chlorophyll content and malic acid content in sugarcane (Cervantesmartinez et al., 2004).

McTaggart et al., (2015) reported that the generation of $\mathrm{CO}_{2}$ from methanol can also occur by PPFM. Increasing $\mathrm{CO}_{2}$ concentration inside stomata led to accelerate the rate of photosynthesis and decrease the rate of photorespiration in $\mathrm{C}_{3}$ plants (Ramirez et al., 2006) because the competition between $\mathrm{CO}_{2}$ and $\mathrm{O}_{2}$ for rubisco enzyme.

\section{Impact of PPFM and PGRs on SPAD and soluble protein content}

Absolute control recorded highest SPAD value (41.87) and control recorded the lowest mean SPAD value (23.00). Among the treatments, BAP recorded the highest SPAD value (40.30) followed by brassinolide (38.72) which is on par with PPFM (37.40) (Table 2). SPAD chlorophyll meter permits a rapid and non-destructive determination of leaf chlorophyll content by measuring leaf transmittance. The SPAD value decreased upon increases in the duration of drought. In the present study, the reduction of SPAD value was recorded up to 45.07 per cent. The higher values of chlorophyll had attributed to an increased photosynthetic rate, resulting in 
higher dry matter production ultimately drought tolerance.

In the present study, foliar application of BAP, brassinolide and PPFM prevent the chlorophyll breakdown under drought leads to retention of chlorophyll and delay of senescence. This result is corroborates with result of Misratia et al., (2013) in rice. Meenakshi and Savalgi (2009) found high chlorophyll content in treatment, which received both seed inoculation and foliar spray of Methylobacterium. Madhaiyan et al., (2004) observed higher photosynthetic activity in rice cultivar $\mathrm{Co}-47$ that received Methylobacterium and attributed the effect due to enhancement of chlorophyll concentration, maleic acid content and increased number of stomata. Using a variety of biochemical and cytological methods, it has been shown that microbes of the genus Methylobacterium produced cytokinin (Koenig et al., 2002). The "classical" phytohormone auxin is also produced and secreted by different strains of Methylobacterium (Hornschuh et al., 2002). Basile et al., (1985) found that the PPFMs influence plant growth by production of phytohormones, such as IAA, cytokinins and vitamins. Anurajan (2003), for the first time reported the production of gibberellic acid by Methylobacterium sp. which acted as plant growth regulator by modifying plant morphology. Jones (2010) observed zeatin production ranging from 0.07 to $1.84 \mu \mathrm{g} / \mathrm{ml}$ by PPFM.

These results clearly indicated that the production and release of important growth promoting substances by non-pathogenic Methylobacteria which might have been involved in the regulation of plant growth and highly correlated with drought tolerance.

Soluble protein content of the leaf, being a measure of RuBP carboxylase activity was considered as an index for photosynthetic efficiency. The rubisco content per unit leaf area was positively correlated with that of soluble protein content of the leaf (Diethelm and Shibles, 1989). The amount of rubisco in leaves is controlled by the rate of synthesis and degradation. However, abiotic stress in tomato (Bartholomew et al., 1991), arabidopsis (Williams et al., 1994) and rice (Vu et al., 1999) leads to a rapid decrease in the abundance of rubisco small subunit $(r b c \mathrm{~S})$ transcripts, which may indicate decreased synthesis. Absolute control recorded the highest soluble protein (14.12 $\left.\mathrm{mg} \mathrm{g}^{-1}\right)$ and lowest was recorded in control $\left(9.58 \mathrm{mg} \mathrm{g}^{-1}\right)$. Brassinolide recorded highest soluble protein (12.25 mg g ${ }^{-1}$ ) followed by PPFM (2\%). The growth regulators and PPFM irrespective of the dose were found to improve the soluble protein content significantly over control.

In the present study, 32.15 per cent of soluble protein content was reduced due to drought stress. The reduction of soluble protein content might be due to the degradation of available soluble protein in plant and reduction of synthesis of enzyme. Among the stress mitigation treatments, foliar spray of brassinolide improved 27.87 per cent of soluble protein followed by 2 per cent PPFM (21.82\%) over control (Table 2). The positive effect of brassinolide on soluble protein content might be due to its involvement in the expression and activation of genes responsible for synthesis of rubisco and rubisco activase (Xia et al., 2009), thereby increasing the capacity of $\mathrm{CO}_{2}$ assimilation in the Calvin cycle. The positive effect of PPFM on soluble protein is might be due to protection of soluble protein degradation under drought.

\section{Impact of PPFM and PGRs on proline}

Proline is believed to protect plant tissues against stress by acting as nitrogen storage, osmoregulator and protectant for enzymes and 
cellular structure. It is one of the important amino acids, is known to occur widely in higher plants and normally accumulates in large quantities in response to environmental stress (Ali et al., 1999). From the current study, it was noted that the higher accumulation of proline was found in drought condition compared to absolute control.

Proline accumulation is a significant response of plant under drought stress. According to Shtereva et al., (2008), PEG induced drought stress increases endogenous proline concentration in tomato. According to Anjum et al., (2000), proline is a scavenger of $\mathrm{OH}^{*}$ radical and plays an important role in osmotic adjustment during oxidative stress. It reduces the damaging effect of ROS to the membrane lipid and protein, enzymes and DNA. Proline has an important role to sustain root growth under water stress condition.

Among the PGRs, the foliar application of PPFM (2\%) increased the proline content by 11.34 per cent followed by brassinolide $(8.34 \%)$ and salicylic acid $(7.89 \%)$ to absolute control. This might be due to the fact that PGRs and PPFM reduced the impact of stress leading to high level of proline accumulation. However, the proline content is higher than control in all the PGRs and PPFM treated plants. Our results are in agreeable with the findings of Uyprasert et al., (2004), who stated that proline acts as a compatible solute and a protective agent for cytoplasmic enzymes and structures. And also they confirmed that the rice genotypes exhibiting high proline accumulation had a marked effect on the ability to maintain water status consequently delayed tissue death and leaf senescence in rice under water stress.

The role of ameliorators such as PPFM and brassinolide was significant in increasing the content of proline in the stressed plants (Aruna et al., 1999). These bioregulators could increase the hydrolysis of macro- molecules into the simpler ones like mono and disaccharides and amino acids especially proline etc. and consequently higher osmolyte concentration resulting in favourable osmoregulation process during water stress conditions. Ameliorants generally maintained higher values of RWC, LWP and proline.

\section{Impact of PPFM and PGRs on NR and catalase activity}

\section{Nitrate reductase (NR)}

It is an important enzyme for nitrogen assimilation and protein synthesis in plant cell which is highly sensitive to any abiotic stress condition. NR activity is vital for the metabolic and physiological status of plants and can be used as a biomarker of plant stress including drought since, nitrate reductase activity decreases in plants exposed to water limitation (Azcon et al., 1996). In the present study also 40.87 per cent reduction of nitrate reductase activity was registered due to 50 per cent drought.

The trend of nitrate reductase activity exhibited significant differences among the treatments are presented. Absolute control recorded the highest nitrate reductase activity (196.78 $\mu \mathrm{g} \quad \mathrm{NO}_{2} \mathrm{~g}^{-1} \mathrm{~h}^{-1}$ ) and lowest was recorded in control (122.27 $\left.\mu \mathrm{g} \mathrm{NO} \mathrm{g}^{-1} \mathrm{~h}^{-1}\right)$. Among the PGRs and PPFM used in this study, salicylic acid recorded highest NR activity (173.24 $\mu \mathrm{g} \mathrm{NO} \mathrm{Ng}^{-1} \mathrm{~h}^{-1}$ ) followed by PPFM (2\%) treatment (172.45 $\left.\mu \mathrm{g} \mathrm{NO}_{2} \mathrm{~g}^{-1} \mathrm{~h}^{-1}\right)$ and brassinolide (171.01 $\mu \mathrm{g} \quad \mathrm{NO}_{2} \mathrm{~g}^{-1} \mathrm{~h}^{-1}$ ) (Graph 1). This shows that the enzyme activity is accelerated by the foliar spray of plant growth regulators and PPFM.

According to the results obtained by the foliar spray of salicylic acid were found effective in improving the nitrate reductase activity with the increase of 33.51 per cent followed by 2 per cent PPFM (31.23\%). SA protects nitrate 
reductase activity and maintains protein and nitrogen content and increases photosynthetic rate and rubisco activity of wheat plants subjected to water deficit as shown by Bhupinder and Usha (2003). The optimistic role of PPFM for the protection of NR activity under drought was observed in the present study. However, the physiological basis for the protection of NR activity by PPFM will be elucidated.

The enzyme catalase involved in the detoxification of reactive oxygen species, especially hydrogen peroxide. In present study, catalase activity increased up to 27.75 per cent due to 50 per cent drought. The plants in absolute control registered minimum enzyme activity of $10.92 \mu \mathrm{g} \mathrm{H}_{2} \mathrm{O}_{2} \mathrm{~g}^{-1} \mathrm{~min}^{-1}$ than control $\left(7.89 \mathrm{H}_{2} \mathrm{O}_{2} \mathrm{~g}^{-1} \min ^{-1}\right)$. Hence, it was showed that catalase activity increased under stress condition. Among the PGRs and PPFM used, 2 per cent PPFM (5.76), brassinolide (6.09) and salicylic acid (6.16 $\mu \mathrm{g}$ $\mathrm{H}_{2} \mathrm{O}_{2} \mathrm{~g}^{-1} \mathrm{~min}^{-1}$ ) were recorded significantly superior catalase activity. Among the PGRs and PPFM, PPFM (2\%) showed higher catalase activity with 27 per cent higher than control followed by brassinolide $(22.81 \%)$ (Graph 2).

Table.1 Impact of PPFM and PGRs on RWC, SPAD value and Photosynthetic rate of tomato under drought at $60 \mathrm{DAT}$

\begin{tabular}{|c|c|c|c|}
\hline Treatments & RWC (\%) & $\begin{array}{l}\text { Photosynthetic rate } \\
\left(\mu \mathrm{mol} \mathrm{m} \mathrm{m}^{-2} \mathrm{~s}^{-1}\right)\end{array}$ & SPAD value \\
\hline $\mathrm{T}_{1}$ : Absolute control & 72.44 & 43.70 & 41.87 \\
\hline $\mathrm{T}_{2}:$ Control & 48.76 & 27.90 & 23.00 \\
\hline $\mathrm{T}_{3}: \operatorname{PPFM}(1 \%)$ & 55.33 & 32.60 & 33.63 \\
\hline $\mathrm{T}_{4}: \mathrm{PPFM}(2 \%)$ & 64.42 & 35.80 & 37.40 \\
\hline $\mathrm{T}_{5}: \mathrm{PPFM}(3 \%)$ & 60.22 & 32.00 & 29.98 \\
\hline $\mathrm{T}_{6}:$ Brassinolide $(1 \mathrm{ppm})$ & 62.66 & 36.43 & 38.72 \\
\hline $\mathrm{T}_{7}:$ Salicylic acid (100 ppm) & 61.24 & 33.90 & 30.90 \\
\hline $\mathrm{T}_{8}: \mathrm{BAP}(100 \mathrm{ppm})$ & 55.80 & 29.60 & 40.30 \\
\hline $\mathrm{T}_{9}: \mathrm{GA}_{3}(10 \mathrm{ppm})$ & 58.33 & 28.90 & 27.98 \\
\hline SE (d) & 1.19 & 0.82 & 0.85 \\
\hline $\mathrm{CD}(\mathrm{P}=0.05)$ & 2.50 & 1.72 & 1.78 \\
\hline
\end{tabular}

Table.2 Impact of PPFM and PGRs on soluble protein and proline content of tomato under drought at $60 \mathrm{DAT}$

\begin{tabular}{|c|c|c|}
\hline Treatments & Soluble protein $\left(\mathrm{mg} \mathrm{g}^{-1}\right)$ & Proline $\left(\mu g^{-1}\right)$ \\
\hline $\mathrm{T}_{1}$ : Absolute control & 14.12 & 162.66 \\
\hline $\mathrm{T}_{2}:$ Control & 9.58 & 293.20 \\
\hline $\mathrm{T}_{3}: \operatorname{PPFM}(1 \%)$ & 10.79 & 302.33 \\
\hline $\mathrm{T}_{4}: \operatorname{PPFM}(2 \%)$ & 11.67 & 326.45 \\
\hline $\mathrm{T}_{5}:$ PPFM $(3 \%)$ & 10.54 & 312.54 \\
\hline $\mathrm{T}_{6}:$ Brassinolide $(1 \mathrm{ppm})$ & 12.25 & 317.64 \\
\hline $\mathrm{T}_{7}:$ Salicylic acid (100 ppm) & 11.02 & 316.32 \\
\hline $\mathrm{T}_{8}: \mathrm{BAP}(100 \mathrm{ppm})$ & 10.66 & 301.10 \\
\hline $\mathrm{T}_{9}: \mathrm{GA}_{3}(10 \mathrm{ppm})$ & 9.80 & 308.12 \\
\hline SE (d) & 0.21 & 6.37 \\
\hline $\mathrm{CD}(\mathrm{P}=\mathbf{0 . 0 5})$ & 1646 & 13.37 \\
\hline
\end{tabular}


Graph.1 Impact of PPFM and PGRs on NR activity $\left(\mu \mathrm{mol} \mathrm{NO}_{2} \mathrm{~g}^{-1} \mathrm{~h}^{-1}\right)$ of tomato under drought at $60 \mathrm{DAT}$

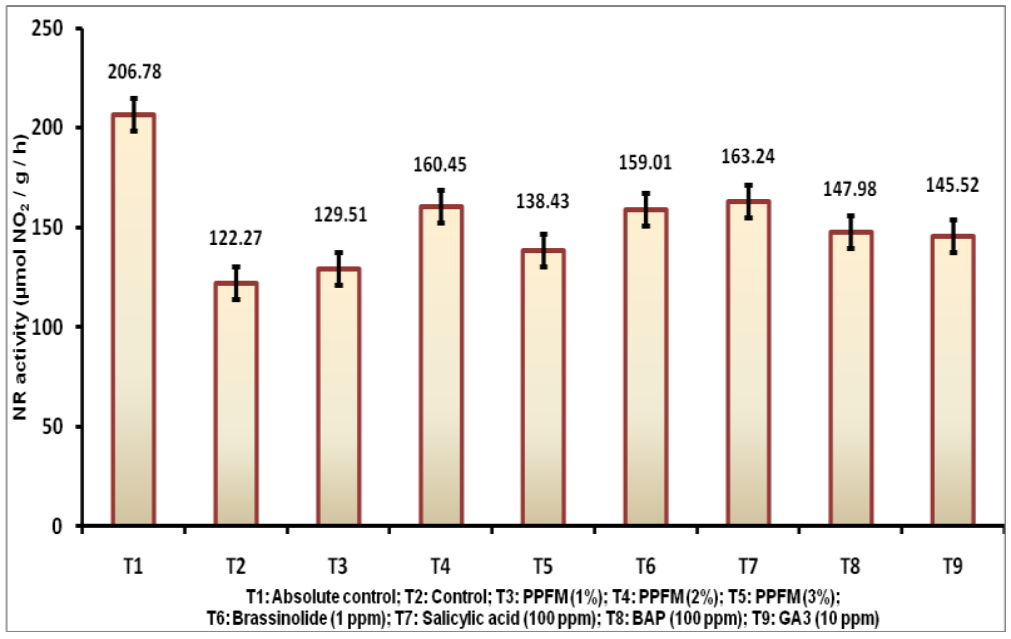

Graph.2 Impact of PPFM and PGRs on catalase activity $\left(\mu \mathrm{g} \mathrm{H}_{2} \mathrm{O}_{2} \mathrm{~g}^{-1} \mathrm{~min}^{-1}\right)$ of tomato under drought at 60 DAT

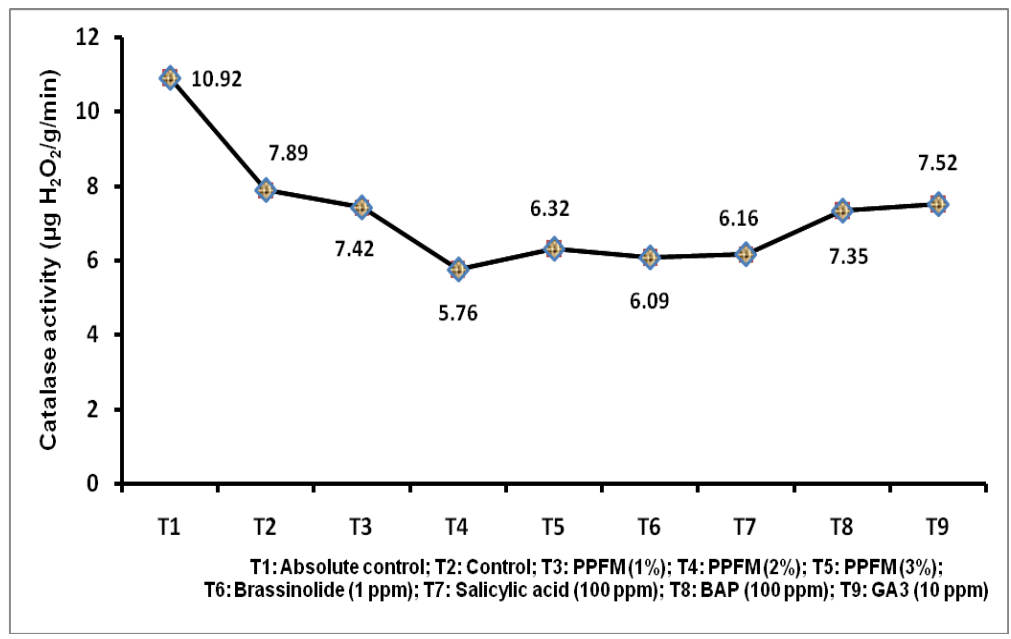

Peroxidases and catalases also play an important role in the fine regulation of reactive oxygen species in the cell through activation and deactivation of several apoplastic enzymes may also generate reactive oxygen species under normal and stressful conditions (Sairam et al., 2005). Among the enzymes, catalase (CAT) is an important and most powerful antioxidant enzyme under abiotic stress condition to nullify the effect of $\mathrm{H}_{2} \mathrm{O}_{2}$ and protects the plants under stress condition. This enzyme is generally regarded as $\mathrm{H}_{2} \mathrm{O}_{2}$ scavenger involved in the reduction of damage by oxidation function (Reddy et al., 2004). Abd El-Gawad et al., (2015) found that the antioxidant enzymes like catalase and SOD activity were increased by the PPFM in snap bean.

In conclusion, agricultural production has been declined year by year due to many abiotic stresses especially drought. Of the various management practices available, mitigation through PGRs and bio-products 
like PPFM are promising to enhance water status of the plant, photosynthetic rate, compatible osmolytes like proline and antioxidant enzyme like catalase activity which protects the plant under any abiotic stress condition. Therefore, these results have practical field application to protect the plant under drought especially PPFM. Further studies would be required to confirm the effect of PPFM through molecular studies.

\section{References}

Abd El-Gawad, H.G. Ibrahim, M.F. Abd ElHafez, A.A. and Abou El-Yazied, A. 2015. Contribution of Pink Pigmented Facultative Methylotrophic Bacteria in Promoting Antioxidant Enzymes, Growth and Yield of Snap Bean. Am.Eur. J. Agric. Environ. Sci. 15 (7): 1331-1345.

Ali, G., Srivastava, P. S. and Iqbal, M. 1999. Proline accumulation, protein pattern and photosynthesis in regenerates grown under $\mathrm{NaCl}$ stress. Biol. Plant, 42: 89-95.

Anjum, F., Rishi, V. and Ahmed, F. 2000. Compatibility of osmolytes with Gibbs energy of stabilization of proteins. Biochem. Biophys. Acta. 1476 (1): 7584.

Anjum, S. A., Xie, X. and Wang, L. 2011. Morphological, physiological and biochemical responses of plants to drought stress. Afr. J. Agric. Res. 6: 2026-2032.

Anjum, S.A., Wang, L.C. Farooq, M. Hussain, M. Xue, L.L. and Zou, C.M. 2011. Brassinolide Application Improves the Drought Tolerance in Maize Through Modulation of Enzymatic Antioxidants and Leaf Gas Exchange. J. Agron. Crop Sci., 197 (3): 177-185.

Anurajan, S. 2003. Studies on the occurrence of pink pigmented facultative methylotrophs on vegetable crops. $\mathrm{M}$.
Sc. (Agri.) Thesis, Tamil Nadu Agricultural University, Coimbatore.

Aruna, T., Kumar, N. and Sairam, R. K. 1999. Efficacy of RWC, membrane stability, osmotic potential, endogenous ABA and root biomass as indices for selection against water stress in rice. Ind. J. Plant Physiol. 4(4): 302-306

Ashraf, M. and Foolad, M. R. 2007. Roles of glycinebetaine and proline in improving plant abiotic stress resistance. Environ. Exp. Bot. 59: 206-16.

Azcon, R., Gomez, M. and Tobar, R. M. 1996. Physiological and nutritional responses by Lactuca sativa $L$. to nitrogen sources and mycorrhizal fungi under drought conditions. Biol. Fertil. Soils. 22: 156-161

Barrs, H. D. and Weatherly, P. E. 1962. A reexamination of the relative turgidity technique for estimating water deficits in leaves. Aust. J. Biol Sci. 15: 413-428.

Bartholomew, D. M., Bartley, G. E. and Scolnik, P. A. 1991. Abscisic-acid control of rbcS and cab transcript ion in tomato leaves. Plant Physiol. 96: 291296.

Basile, D. V., Basile, M. R. Li, Q. Y. and Corpe, W. A. 1985. Vitamin B 12 stimulated growth and development of Jungermannia leiantha Grolle and Gymnocolea inflate Dum. (Hepaticae). Bryologist. 88: 77-81

Bates, L. S., Waldren, R. P. and Teare, I. D. 1973. Rapid determination of proline for water stress studies. Plant Soil. 39: 205-207.

Bhupinder, S. and Usha, K. 2003. Salicylic acid induced physiological and biochemical changes in wheat seedlings under water stress. Plant Growth Regul. 39:137-141.

Braun, P. and Wild, A. 1984. The influence of brassinosteroid on growth parameters of wheat and mustard plants. J. Plant Physiol. 116: 189-96. 
Cervantes-martinez, J., Lopez-diaz, S. and Rodrigue z-garay, B. 2004. Detection of the effects of Methylobacterium in Agave tequilana Weber var. azulby laser induced fluorescence. Plant Sci. 166: 889-892.

Chakrabarti, N. and Mukherji, S. 2002. Effect of phytohormone pre-treatment on metabolic changes in Vigna radiate under salt stress. J. Environ. Biol. 23: 295-300.

Cortina, C. and Culianez-Macia, F.A. 2005. Tomato abiotic stress enhanced tolerance by trehalose biosynthesis. Plant Sci. 169(1): 75-82.

Diethelm, R. and Shibles, R. 1989. Relationship of enhanced sink de-mand with photosynthesis and amount and activity of ribulose 1, 5-bisphosphate carboxylase in soybean leaves. J. Plant Physiol. 134: 70-74.

Dwivedi, S.K., Kumar, S. Mondal, S. Malviya, N. and Dubey, R. 2014. Physiological Basis of Cytokinin induced Drought Tolerance in Wheat (Triticum aestivum L.). J. Agri Search. 1(3): 139-144.

Gomez, K. A. and Gomez, A. A. 1984. Statistical procedures for agricultural research. (2nd Ed.) John Wiley and sons, New York, USA.

Gopalachari, N. C. 1963. Changes in the activities of certain oxidizing enzymes during germination and seedling development of Phaseolus mungo and Sorghum. Ind. J. Exp. Biol. 1: 98-100.

Green, P. N. and Bousfield, I. J. 1983. Emendation of Methylobacterium Patt, Cole, and Hanson 1976; Methylobacterium rhodinum (Heumann, 1962) comb. nov. corrig.; Methylobacterium radiotolerans (Ito and lizuka, 1971) comb. nov. corrig.; and Methylobacterium mesophilicum (Austin and Goodfellow 1979) comb. nov. Int. J. Syst. Bacteriol., 33: 875877.

Haloi, B. and Baldev, B. 1986. Effect of irrigation on growth attributes in chickpea when grown under different dates of sowing and population pressure. Indian J. Plant Physiol. 24: 14-27.

Hayat, Q., Hayat, S. Irfan, M. and Ahmad, A. 2010. Effect of exogenous salicylic acid under changing environment: a review. Environ. Exp. Bot. 68(1): 14-25.

Hayat, S., Hasan, S. A. Fariduddin, Q. and Ahmad, A. 2008. Growth of tomato (Lycopersicon esculentum) in response to salicylic acid under water stress. J. Plant. Interact. 3(4): 297-304.

Hornschuh, M., Grotha, R. and Kutschera, U. 2002. Epiphytic bacteria associated with the bryophyte Funaria hygrometrica: Effects of Methylobacterium strains on protonema development. Plant Biol. 4: 682-7.

Jones, N. P. 2010. Molecular diversity of Arbuscular mycorrhizal fungi and pink pigmented facultative methylotrophic bacteria and their influence on grapevine (Vitis vinifera). Ph. D. (Agri.) Thesis, Univ. Agric. Sci., Dharwad (India).

Katerji, N., Van Hoorn Hamdy, J. W. Mastrorilli, A. and Mou Karzel, E. 1997. Osmotic adjustment of sugar beets in response to soil salinity and its influence on stomatal conductance, growth and yield. Agric. Water Manage. 34: 57-69.

Koenig, R. L., Morris, R. O. and Polacco, J. C. 2002. tRNA is the source of low level trans-zeatin production in Methylobacterium spp. J. Bacteriol. 184: 1832-1842.

Li, Z. R., Wakao, S. Fischer, B. B. and Niyogi, K. K. 2009. Sensing and responding to excess light. Annu. Rev. Plant Biol. 60: 239-260.

Lowry, O. H., Rosebrough, N. J. Farr, A. L. and Randall, R. J. 1950. Protein 
measurement with the folin phenol reagent. J. Biol. chem. 193(1): 265-275. Madhaiyan, M., Poonguzhali, S. Senthilkumar, M. Sundaram, S. Heekyung, C. Jinchul, Y. Subbiah, S. and Tongmin, S. A. 2004. Growth promotion and induction of systemic resistance in rice cultivar Co-47 (Oryza sativa L.) by Methylobacterium spp. Bot. Bull. Acad. Sin. 45: 315-324.

Maggio, A., Barbieri, G. Raimondi, G. and De Pascale, S. 2010. Contrasting effects of $\mathrm{GA}_{3}$ treatments on tomato plants exposed to increasing salinity. J. Plant Growth Regul. 29: 63-72.

McTaggart, T., Beck, D. Setboonsarng, U. Shapiro, N. Woyke, T. Lidstrom, M. Kalyuzhnaya, M. and Chistoserdova, L. 2015. Genomics of methylotrophy in gram-positive methylamine-utilizing bacteria. Microorganisms. 3: 94-112

Meenakshi, B. C. and Savalgi, V. P. 2009. Effect of co-inoculation of Methylobacterium and Bradyrhizobium japonicum on plant growth dry matter content and enzyme activities in soybean. Karnataka J. Agric. Sci. 22: 344-348.

Misratia, K. M., Ismail, M. R. Hakim, M. A. Musa, M. H. and Puteh, A. 2013. Effect of salinity and alleviating role of gibberellic acid $\left(\mathrm{GA}_{3}\right)$ for improving the morphological, physiological and yield traits of rice varieties. Aust. J. Crop Sci. 7: 1682-1692.

Nair, V. D., Cheruth, A. J. Gopi, R. Gomathinayagam, M. and Panneerselvam, R. 2009. Antioxidant potential of Ocimum sanctum under growth regulator treatments. Eur. Asia J. BioSci. 3: 1-9.

Nicholas, J. C., Harper, J. E. and Hageman, R. H. 1976. Nitrate reductase activity in soybeans. Effect of light and temperature. Plant Physiol. 58: 731735.
Qayyum, M. A. and Malik, M. D. 1988. Farm production losses in salt affected soils. Proc.1st Nat. Congr. Soil Sci. Lahore, Oct., 356- 364.

Ramirez, I., Dorta, F. Espinoza, V. Jimenez, E. Mercado, A. and Cortes, H.P.A. 2006. Effects of foliar and root applications of methanol on the growth of Arabidopsis, tobacco and tomato plants. J. Plant Growth Regulat. 25: 3044.

Reddy, A. R., Chaitanya, K. V. and Vivekanandan, M. 2004. Droughtinduced responses of photosynthesis and antioxidant metabolism in higher plants. J. Plant Physiol. 161: 1189 1202.

Sairam, R. K., Srivastava, G. C. Agarwal, S. and Meena, R. C. 2005. Differences in antioxidant activity in response to salinity stress in tolerant and susceptible wheat genotypes. Biol. Plant. 49: 8591.

Saruhan, N., Saglam, A. and Kadioglu, A. 2012. Salicylic acid pretreatment induces drought tolerance and delays leaf rolling by inducing antioxidant systems in maize genotypes. Acta Physiologiae Plantarum. 34 (1): 97-106

Shtereva, L., Atanassova, B. Karcheva, T. and Petkov, V. 2008. The effect of water stress on the growth rate, water content and proline accumulation in tomato calli and seedlings. Acta hort. 789: 189-197.

Tuna, A. L., Kaya, C. Dikilitas, M. and Higgs, D. 2008. The combined effects of gibberellic acid and salinity on some antioxidant enzyme activities, plant growth parameters and nutritional status in maize plants. Environ. Exp. Bot. 62: $1-9$.

Uyprasert, S., Toojinda, T. Udompraset, N. Tragoonrung, S. and Vanavichit, A. 2004. Proline accumulation and rooting patterns in rice in response to water 
deficit under rainfed lowlands. Sci. Asia. 30: 301-311.

Van Loon, L. C., Bakker, P. A. H. M. and Pieterse, C. M. J. 1998. Systemic resistance induced by rhizosphere bacteria. Ann. Rev. Phytopath. 36: 453483.

Vardhini, B. V. and Rao, S. S. R. 2001. Effect of brassinosteroids on growth and yield of tomato (Lycopersicon esculentum Mill.) under field conditions. Indian $J$. Plant Physiol. 6:326-328.

Vu, J. C. V., Gesch, R. W. Allen, L. H. Boote, K. J. and Bowes, G. 1999. $\mathrm{CO}_{2}$ enrichment delays a rapid, droughtinduced decrease in Rubisco small subunit transcript abundance. J. Plant Physiol. 155: 139-142.

Williams, S. J., Bulman, M. P. and Neill, S. J. 1994. Wilt-induced ABA biosynthesis, gene-expression and down-regulation of rbcS messenger RNA levels in Arabidopsis thaliana. Physiol. Plant.
91: 177-182.

Xia, X. J., Huang, L. F. Zhou, Y. H. Mao, W. H. Shi, K. Wu, J. X. Asami, T. Chen, Z. and $\mathrm{Yu}$, J. Q. 2009. Brassinosteroids promote photosynthesis and growth by enhancing activation of Rubisco and expression of photosynthetic genes in Cucumis sativus. Planta. 230 (6): 11851196.

Yu, J. Q., Huang, L. F. Hu, W. H. Zhou, Y. H. Mao, W. H. and Nogues, S. 2004. A role for brassinosteroids in regulation of photosynthesis in Cucumis sativus. J. Exp. Bot. 55: 1135-1143.

Zhang, M., Duan, L. Zhai, Z. Li, J. Tian, X. Wang, B. He, Z. and Li, Z. 2004. Effects of plant growth regulators on water deficit-induced yield loss in soybean, Proceedings of the 4th International Crop Science Congress Brisbane, Australia.

\section{How to cite this article:}

Sivakumar, R., G.K. Nandhitha, P. Chandrasekaran, P. Boominathan and Senthilkumar, M. 2017. Impact of Pink Pigmented Facultative Methylotroph and PGRs on Water Status, Photosynthesis, Proline and NR Activity in Tomato under Drought. Int.J.Curr.Microbiol.App.Sci. 6(5): 1640-1651. doi: https://doi.org/10.20546/ijcmas.2017.606.192 